\title{
Virucidal activity of Colombian Lippia essential oils on dengue virus replication in vitro
}

\author{
Raquel Elvira Ocazionez ${ }^{1 /+}$, Rocio Meneses ${ }^{1}$, Flor Ángela Torres ${ }^{1}$, Elena Stashenko ${ }^{2}$
}

\begin{abstract}
${ }^{1}$ Laboratorio de Arbovirus, Centro de Investigaciones en Enfermedades Tropicales ${ }^{2}$ Centro de Investigación en Biomoléculas, Centro Nacional de Investigaciones para la Agroindustrialización de Especies Vegetales Aromáticas y Medicinales Tropicales, Universidad Industrial de Santander, Bucaramanga, Colombia
\end{abstract}

The inhibitory effect of Lippia alba and Lippia citriodora essential oils on dengue virus serotypes replication in vitro was investigated. The cytotoxicity $\left(C C_{50}\right)$ was evaluated by the MTT assay and the mode of viral inhibitory effect was investigated with a plaque reduction assay. The virus was treated with the essential oil for $2 \mathrm{~h}$ at $37^{\circ} \mathrm{C}$ before cell adsorption and experiments were conducted to evaluate inhibition of untreated-virus replication in the presence of oil. Antiviral activity was defined as the concentration of essential oil that caused $50 \%$ reduction of the virus plaque number $\left(I C_{50}\right)$. L. alba oil resulted in less cytotoxicity than L. citriodora oil $\left(C C_{50}: 139.5 \mathrm{vs} .57 .6 \mu \mathrm{g} / \mathrm{mL}\right)$. Virus plaque reduction for all four dengue serotypes was observed by treatment of the virus before adsorption on cell. The IC $C_{50}$ values for L. alba oil were between 0.4-32.6 $\mu \mathrm{g} / \mathrm{mL}$ and between 1.9-33.7 $\mu \mathrm{g} / \mathrm{mL}$ for $\mathrm{L}$. citriodora oil. No viral inhibitory effect was observed by addition of the essential oil after virus adsorption. The inhibitory effect of the essential oil seems to cause direct virus inactivation before adsorption on host cell.

Key words: essential oil - antiviral - virucidal activity - dengue virus - Lippia sp.

Dengue is an acute illness characterised by the hemorrhagic fever caused by dengue virus (DENV) that is transmitted to humans by Aedes mosquitoes. DENV infection results in a spectrum of disease ranging from a mild febrile illness or dengue fever to a severe disease or dengue hemorrhagic fever/dengue shock syndrome. Among the human arboviral diseases, dengue is responsible for causing most illness and death. It has been estimated that 50-100 million dengue infections occur each year in tropical urban areas around the world with 20,000-25,000 deaths (Gubler 2006).

DENV is a member of the Flaviviridae family and it exists as four related serotypes (DENV-1 2, 3 and 4). The virus possesses an icosahedral nucleocapsid core surrounded by a host-derived lipid membrane (envelope), in which the envelope (E) protein and membrane (M) protein are embedded. The Flavivirus enters into the host cell by receptor-mediated endocytosis into coated vesicles, a process in which the $\mathrm{E}$ protein plays the major role. The E protein mediates interactions within the virus and the components of the host cell membrane involved in virus adsorption and the E protein interacts with the membrane cell during fusion (Lindenbach \& Rice 2007). Compounds that interact with sites on the $E$ protein that binds to structures on the cellular membrane affect the adsorption and fusion process. That interferes

Financial support: COLCIENCIAS (RC-432-2004)

+Corresponding author: relocaz@uis.edu.co

Received 23 September 2009

Accepted 3 February 2010 with virus penetration into the cellular cytoplasm and consequently its subsequent replication (Leysen et al. 2000, Patkar \& Kuhn 2006).

There is no antiviral drug for treatment for any of the Flavivirus and an effective vaccine for human use is not yet available to prevent dengue. Consequently, the development of antiviral drugs licensed for treatment of patients remains an urgent need to prevent dengue fatalities. Compounds obtained from traditional medicinal plants and herbs species have been reported to have antiviral activity and a wide variety of active phytochemicals have been identified (Jassim \& Naji 2003). There is evidence that shows that essential oils from various herb species can directly inactivate the virus. Inhibition of enveloped virus subsequent replication in vitro (herpes simplex virus, hepatitis B virus and human immunodeficiency virus) is observed by incubation of the virus with essential oil before cell adsorption (Yamasaki et al. 1998, Zhang et al. 1998, Saddi et al. 2007).

To our knowledge, relatively little is known about antiviral activity of compounds obtained from plants on flavivirus. Recently, we reported the inhibitory effect of essential oils obtained from Colombian plants on yellow fever virus replication in vitro. Incubation of virus with Lippia alba, Lippia origanoides, Oreganium vulgare and Artemisia vulgaris essential oils before cell adsorption inhibited more than $50 \%$ the subsequent extracellular virus progeny at concentrations between 3.7-11.1 $\mu \mathrm{g}$ / $\mathrm{mL}$ (Meneses et al. 2009).

The objective of this study was to evaluate the inhibitory effect of essential oils obtained from $L$. alba and Lippia citriodora grown in Colombia on DENV replication in vitro. Plants are widely used to alleviate almost any digestive, liver and respiratory diseases. It is suggested that some of the medicinal properties could be related to essential oil components (Pascual et al. 2001). 


\section{SUBJECTS, MATERIALS AND METHODS}

Plants - Propagation cuttings were obtained from $L$. $a l b a$ and $L$. citriodora growing wild in Cundinamarca and Antioquia regions, Colombia. The cuttings were used to establish experimental contiguous plots at the Centro Nacional de Investigaciones para la Agroindustrialización de Especies Vegetales Aromáticas y Medicinales Tropicales Agroindustrial - Pilot Complex, located at the main campus of Universidad Industrial de Santander (Bucaramanga). Voucher specimens from each plant were deposited at the Colombian National Herbarium and the taxonomic identifications were performed by Dr. José Luis Fernández (National Herbarium, UN, Bogotá, Colombia).

Essential oil - The air-dried plant material was submitted to the microwave-assisted hydrodistillation in a Clevenger-type apparatus, as described elsewhere (Stashenko et al. 2004). To determine the identity of the essential oils tested, their chemical composition was analysed qualitatively and quantitatively using chromatographic (retention times, retention indices and standards) and spectroscopic (spectral interpretation, comparison with databases and standards) criteria (Stashenko et al. 2004, 2008). Two GC-MS systems were employed: an Agilent Technologies 6890 Plus gas chromatograph (Palo Alto, CA, USA) equipped with an Agilent Technologies $5973 \mathrm{~N}$ mass selective detector and an Agilent Technologies 6890 gas chromatograph coupled to an Agilent Technologies 5975 mass selective detector. Both systems were equipped with a split/splitless injector (split ratio 1:50), a 7863 automatic injector and an MS-ChemStation G1701DA data system that included the WILEY 138K, NIST 2002 and QUADLIB 2004 spectral libraries. A fused silica capillary column DB-5MS (J\&W Scientific, Folsom, CA, USA) of $60 \mathrm{~m} \times 0.25 \mathrm{~mm}$ ID $\times 0.25 \mu \mathrm{m}, \mathrm{d}_{\mathrm{f}}$ and a fused silica DB-WAX (J\&W Scientific, Folsom, CA, USA) $60 \mathrm{~m} \times 0.25 \mathrm{~mm}$, ID x $0.25 \mu \mathrm{m}, \mathrm{d}_{\mathrm{f}}$ column were employed. The oven temperature was initially programmed from $45^{\circ} \mathrm{C}(5 \mathrm{~min})$ to $150^{\circ} \mathrm{C}(2 \mathrm{~min})$ at $4^{\circ} \mathrm{C} \mathrm{min}{ }^{-1}$, followed by $250^{\circ} \mathrm{C}(5 \mathrm{~min})$ at $5^{\circ} \mathrm{C} \mathrm{min}^{-1}$ and finally to $275^{\circ} \mathrm{C}(15 \mathrm{~min})$ at $10^{\circ} \mathrm{C} \mathrm{min}^{-1}$. The ionisation chamber and transfer line temperatures were kept at $230^{\circ} \mathrm{C}$ and $285^{\circ} \mathrm{C}$, respectively. Plant local names, voucher numbers and the main essential oil components are shown in Table I. For the antiviral assays, the essential oil was dissolved in a solution of $1 \%$ dimethyl sulfoxide in test medium.

Cell culture and virus - African green monkey kidney cells (Vero) were maintained in minimum essential medium (M-199) supplemented with $10 \%$ foetal calf serum (FCS) and $0.07 \% \mathrm{NaHCO}_{3}$ at $37^{\circ} \mathrm{C}$ in a humidified $5 \%-\mathrm{CO}_{2}$ atmosphere. DENV-1, DENV-2, DENV-3 and DENV-4 isolated from Colombian patients suffering dengue were included. The viruses were selected from the Arbovirus Laboratory collection at Laboratorio de Arbovirus, Centro de Investigaciones en Enfermedades Tropicales, Industrial University of Santander. YFV 17 DD was included in the study as positive control. Vero cell cultures were infected with the virus at one multiplicity of infection. Four to five days later, the viral supernatant consisting of culture medium was harvested and clarified by centrifugation at $400 \mathrm{~g}$ at $4^{\circ} \mathrm{C}$. Virus titer, expressed as plaque-formation unit per millilitre (PFU/mL), was determined by standard plaque assay on Vero cells grown in 24-well plates, as previously described (Meneses et al. 2009). DENV stocks were stored in suitable aliquots at $-80^{\circ} \mathrm{C}$ until used.

Cytotoxicity assay - For cytotoxicity of the essential oils tested, the MTT assay was used following the protocol described in a previous study (Meneses et al. 2009). Briefly, Vero cells were seeded into 96-well plates at 1 x $10^{3}$ cells per well and incubated for $24 \mathrm{~h}$ at $37^{\circ} \mathrm{C}$. The medium was removed and the M-199 medium containing the essential oil was added for $72 \mathrm{~h}$ at $37^{\circ} \mathrm{C}$ at concentrations of $900,300,100$ and $3.7 \mu \mathrm{g} / \mathrm{mL}$. Subsequently, the culture medium was removed and the MTT solution $(10 \mu \mathrm{L}, 5 \mathrm{mg} / \mathrm{mL}$, Sigma Co) was added to each well. Cytotoxicity effect of the essential oil was defined as the $50 \%$ reduction of cell viability of treated culture cells with respect to untreated culture $\left(\mathrm{CC}_{50}\right)$. The $\mathrm{CC}_{50}$ values were calculated using the xl-fit for Windows software, version 4.0. Each essential oil was tested in triplicate in two independent experiments.

Mode of antiviral activity - To determine the inhibitory effect of the selected essential oils on DENV replication in vitro, a plaque reduction assay was used with monolayer cultures of Vero cells grown in 24-well plates. A modified protocol described by Saddi et al. (2007) was followed.

The virus (80-100 PFU of DENV-1, 2, 3 or 4) was incubated before adsorption with varying concentrations of the essential oil $(0.02,0.1,2.5,12.5,62.5$ and $312.5 \mu \mathrm{g} /$ $\mathrm{mL}$ ) for $2 \mathrm{~h}$ at $37^{\circ} \mathrm{C}$ in M-199 with $2 \%$ FCS. Vero cells were infected in duplicate with treated virus. After a $1 \mathrm{~h}$ period at $37^{\circ} \mathrm{C}$, the cells were washed twice, followed by the incubation at $37^{\circ} \mathrm{C}$ in $\mathrm{M}-199$ medium containing $5 \%$ FCS and $3 \%$ carboxymethyl-cellulose $(0.5 \mathrm{~mL} /$ well plate). After six days of incubation at $37^{\circ} \mathrm{C}$ in a humidified $5 \%-\mathrm{CO}_{2}$ atmosphere, medium was removed and cell monolayers were fixed with formaldehyde $(10 \%)$ for $1 \mathrm{~h}$ at RT, followed by staining (15-30 s) with a $1 \%$ crystal violet solution. The stain was removed and the plaques were counted. Two independent experiments were performed for each viral serotype and for each essential oil.

Experiments were also performed to determine the viral inhibitory effect of the selected essential oils after adsorption during the intracellular replication period. Vero cells grown in 24-well plates were infected in duplicate with 50-60 PFU of DENV (1, 2, 3 or 4). After $1 \mathrm{~h}$ adsorption at $37^{\circ} \mathrm{C}$ plates were washed and medium was replaced with MEM, 5\% FCS, 3\%carboxymethyl-cellulose containing test essential oil concentrations described above $(0.5 \mathrm{~mL} /$ well plate). After six days of incubation, monolayers of cells were stained and the plaques were counted. Two independent experiments were performed for each viral serotype and for each of the test essential oil.

Infected cells with untreated virus were used as control in all experiments. Antiviral effect of the essential oil was defined as the $50 \%$ reduction of the plaque numbers formed by treated virus relative to the untreated virus $\left(\mathrm{IC}_{50}\right)$. The $\mathrm{IC}_{50}$ values were calculated by regression analysis of the dose-response curves generated from the data. 
TABLE I

Plants used in the study

\begin{tabular}{|c|c|c|c|}
\hline Species & Local name & $\begin{array}{l}\text { Voucher } \\
\text { (COL) }\end{array}$ & $\begin{array}{l}\text { Main essential oil components } \\
\qquad \%\end{array}$ \\
\hline Lippia alba & Pronto alivio & 480750 & $\begin{array}{c}\text { Carvone: } 39.7 \\
\text { Limonene: } 30.6 \\
\text { Bicyclosesquiphellandrene: } 8.9 \\
\text { Piperitenone: } 4.5 \\
\text { Piperitone: } 2.8 \\
\beta \text {-bourboneno: } 1.7\end{array}$ \\
\hline Lippia citriodora & Verbena olorosa & 480749 & $\begin{array}{c}\text { Geranial: } 18.9 \\
\text { Neral: } 15.6 \\
\text { Limonene: } 10.7 \\
\text { 1,8-Cineole: } 5.0 \\
\text { Spathulenol: } 4.7 \\
\text { Geraniol: } 2.7 \\
\text { trans- } \beta \text {-cariofilene: } 2.3 \\
\text { Nerol: } 2.0 \\
\text { Geranyl acetate: } 1.3\end{array}$ \\
\hline
\end{tabular}

COL: Colombian National Herbarium.

\section{RESULTS}

The effect of the essential oils on the proliferation and viability of the mammalian cells was tested prior to the determination of their viral inhibitory effect, using the MTT reduction assay on Vero cell monolayers. The $\mathrm{CC}_{50}$ for L. alba oil was $139.5 \mu \mathrm{g} / \mathrm{mL}$ and for L. citriodora oil it was $57.6 \mu \mathrm{g} / \mathrm{mL}$.

Antiviral activities of the selected essential oils were examined by using the plaque reduction assay. Relevant and selectivity activity was defined adopting standard criteria (Cos et al. 2006). Specifically, we have used the following criteria: $\mathrm{CC}_{50}$ value $\geq 100 \mu \mathrm{g} / \mathrm{mL}, \mathrm{IC}_{50}$ value $\leq$ $50 \mu \mathrm{g} / \mathrm{mL}$ and selectivity index or ratio $\mathrm{CC}_{50} / \mathrm{IC}_{50} \geq 2.0$. The abilities of the essential oils to directly inactivate virus (virucidal action) were evaluated. Virus incubation with oil for $2 \mathrm{~h}$ at $37^{\circ} \mathrm{C}$ before adsorption on Vero cell inhibited the subsequent viral replication. The doseresponse curves shown in Figs 1 and 2 demonstrate a dose-dependent virucidal action of the tested essential oils. A 50\% inhibition of plaque formation was observed against all examined viruses.

Virucidal action, as measured by the $\mathrm{IC}_{50}$ and the selectivity index varied depending on the virus serotype and test essential oil used (Table II). For L. alba, $\mathrm{IC}_{50}$ values were between $0.4-33 \mu \mathrm{g} / \mathrm{mL}$ with selectivity indices ranging from 4-349. According to the $\mathrm{IC}_{50}$ values, this essential oil was more active against DENV-2 than other serotypes, in particular DENV-3 ( $p<0.001$, ANOVA test). For L. citriodora, the $\mathrm{IC}_{50}$ values were between 1.9$33.7 \mu \mathrm{g} / \mathrm{mL}$ with selectivity indices ranging from 2-30. The virucidal action against DENV-1, 2 and 3 of the $L$. citriodora essential oil was not different but it was lower against DENV-4 ( $\mathrm{p}<0.001$, ANOVA test). As expected, the examined essential oils were active against YFV $\left(\mathrm{IC}_{50}<6 \mu \mathrm{g} / \mathrm{mL}\right.$; selectivity index: 28$)$.

No viral inhibition was observed by plaque reduction assay when the cells were infected with untreated DENV-1, 2, 3 or 4 and then incubated for virus replication in M-199 medium containing various concentrations of the L. alba essential oil. A dose-dependent antiviral action of the test essential oil was not observed. The $\mathrm{IC}_{50}$

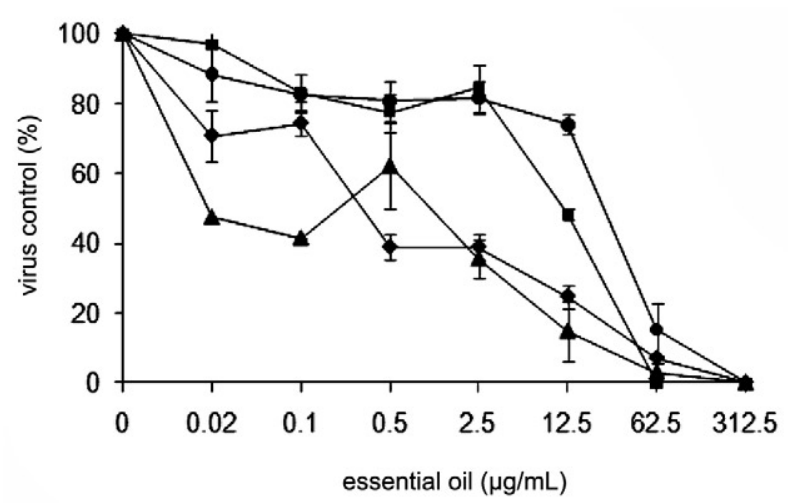

Fig. 1: virucidal activity of Lippia species essential oils from Colombia on dengue virus replication in vitro. Effect of Lippia alba essential oil on plaque formation by dengue virus (DENV)-1 (๘), DENV-2 (४), DENV-3 (४) and DENV-4 (•) before adsorption on cell. Virus (80-100 plaque-formation unit) was pre-incubated for $2 \mathrm{~h}$ at $37^{\circ} \mathrm{C}$ in the presence of essential oil at varied concentrations and then adsorbed on Vero cells. Reduction of the viral plaque number was determined six days after cellular infection. The data represent the means for two replicate samples of two independent experiments. 


\section{TABLE II}

Virucidal activity of the essential oil obtained from Colombian plants determined by plaque reduction assay

\begin{tabular}{lcccc}
\hline & \multicolumn{2}{c}{$\begin{array}{c}\text { Lippia alba } \\
\mathrm{CC}_{50}: 139.5 \mu \mathrm{g} / \mathrm{mL}\end{array}$} & \multicolumn{2}{c}{$\begin{array}{c}\text { Lippia citriodora } \\
\mathrm{CC}_{50}: 57.6 \mu \mathrm{g} / \mathrm{mL}\end{array}$} \\
\cline { 2 - 5 } Virus & $\mathrm{IC}_{50}(\mu \mathrm{g} / \mathrm{mL})$ & $\mathrm{SI}$ & $\mathrm{IC}_{50}(\mu \mathrm{g} / \mathrm{mL})$ & $\mathrm{SI}$ \\
\hline DENV-1 & $10.1 \pm 1.5$ & 14 & $1.9 \pm 0.9$ & 30 \\
DENV-2 & $0.4 \pm 0.2$ & 349 & $2.9 \pm 0.8$ & 20 \\
DENV-3 & $32.6 \pm 4.3$ & 4 & $2.6 \pm 0.1$ & 22 \\
DENV-4 & $21.1 \pm 3.2$ & 7 & $33.7 \pm 3.3$ & 2 \\
YFV 17 DD & $4.9 \pm 1.7$ & 28 & $5.7 \pm 0.8$ & 10 \\
\hline
\end{tabular}

virus was incubated for $2 \mathrm{~h}$ at $37^{\circ} \mathrm{C}$ with concentrations of essential oil and then was adsorbed on Vero cells. SI: selectivity index $\left(\mathrm{CC}_{50} / \mathrm{IC}_{50}\right)$.

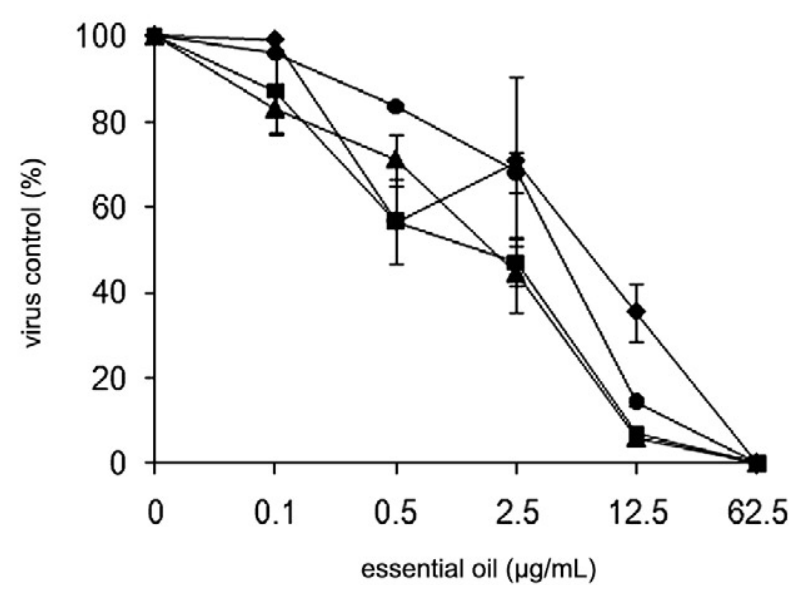

Fig. 2: virucidal activity of Lippia species essential oils from Colombia on dengue virus replication in vitro. Effect of Lippia citriodora essential oil on plaque formation by dengue virus (DENV)-

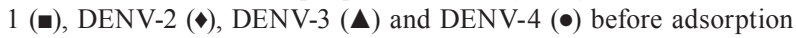
on cell. Virus (80-100 plaque-formation unit) was pre-incubated for 2 $h$ at $37^{\circ} \mathrm{C}$ in the presence of essential oil at varied concentrations and then adsorbed on Vero cells. Reduction of the viral plaque number was determined six days after cellular infection. The data represent the means for two replicate samples of two independent experiments.

values were estimated to be more than $312.5 \mu \mathrm{g} / \mathrm{mL}$ for all DENV serotypes (Fig. 3), with the selectivity indices less than 1.7. The results found with $L$. alba oil were also observed with the L. citriodora essential oil. At the maximum oil concentration $(62.5 \mu \mathrm{g} / \mathrm{mL})$ used in the antiviral assay, the reduction of the viral plaque number was 12 , 22,38 and $42 \%$ for DENV-1, 2, 3 and 4, respectively.

Taken together, the results suggest that the action of the essential oils as inhibitory agents of DENV infectivity is due to direct virus inactivation, preventing adsorption and subsequent cellular infection.

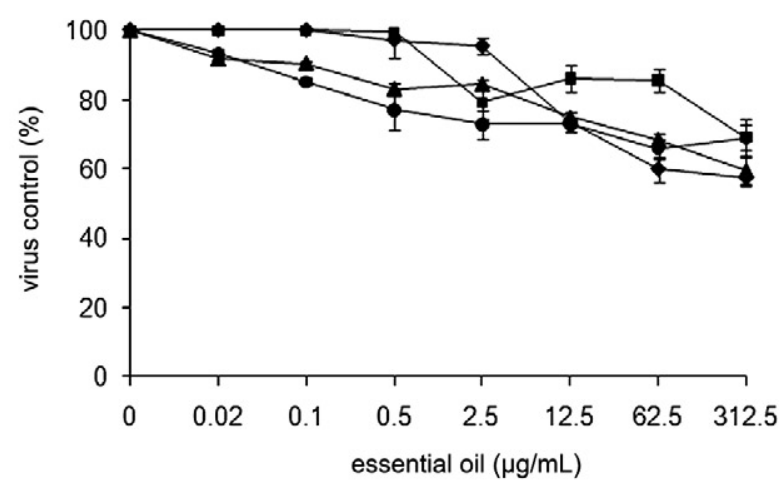

Fig. 3: virucidal activity of Lippia species essential oils from Colombia on dengue virus replication in vitro. Effect of Lippia alba essential oil on plaque formation by dengue virus (DENV)-1 (๘), DENV-2 ( $\bullet$, DENV-3 (४) and DENV-4 $(\bullet)$ after adsorption on cell. Monolayers of Vero cell were infected with 50-60 plaque-formation unit of virus and then incubated at $37^{\circ} \mathrm{C}$ in the presence of cellular medium containing essential oil at varied concentrations. Reduction of the viral plaque number was determined six days after cellular infection. The data represent the means for two replicate samples of two independent experiments.

\section{DISCUSSION}

Various studies have been conducted exploring the antiviral activity of chemical compounds against DENV. Some compounds are small molecules that can inhibit specific steps of intracellular replication of the virus and other compounds are inhibitors of viral proteins (Leyssen et al. 2000, Patkar \& Kuhn 2006, Zhou et al. 2008, Wang et al. 2009). Although some compounds have shown promising results, none of these compounds has been approved for use in humans. Plant-derived drugs remain an important resource for treatment of tropical disease like dengue, especially in developing countries.

The Lippia species are mainly distributed throughout the South and Central America and African countries (Terblanché \& Kornelius 1996). Infusions of $L . a l b a$ and L. citriodora are used as a remedy for colds, influenza, bronchitis, coughs and asthma. These species are also considered very useful for treatment of stomach-ache, indigestion, hepatic disorders and to soothe vesicle pain. It is suggested that medicinal properties of the Lippia species can be due to the essential oils (Pascual et al. 2001).

In this study, the cytotoxicity of the $L$. alba and $L$. citriodora essential oils was tested on the Vero cells. Cytotoxicity of the essential oils examined can be rated as low to moderate based on the $\mathrm{CC}_{50}$ classification system of Halle and Göres (1987). The results revealed L. alba as low cytotoxic and L. citriodora 2.4 times more cytotoxic. The essential oil of $L$. citriodora has geranial and neral components (Table I) as well as a mixture of these results in a citral compound. We have observed that the incubation of Vero cells with citral at a concentration as low as $32 \mu \mathrm{g} / \mathrm{mL}$ for $24 \mathrm{~h}$ at $37^{\circ} \mathrm{C}$ inhibited the cellular proliferation and viability in MTT assays by $50 \%$ (unpublished data). It remains be explored whether the higher cytotoxicity activity of the L. citriodora essential oil is due to the presence of geranial and neral compounds. 
To determine the antiviral action of the essential oils tested in this study, DENV was treated before adsorption on Vero cell without dilution of the virus-oil mixture to eliminate the oil. Under these conditions, the assay might not allow precise discrimination between antiviral and virucidal action because the oil could enter into the cells and interfere with the intracellular steps of the viral cycle. We can conclude presence of the virucidal effect and rule out antiviral activity of the essential oils. This is because the presence of tested essential oils in the culture medium during replication of untreatedDENV did not cause significant reduction of the viral plaque numbers six days after cellular virus infection (Fig. 3). In a previous study, we did not observe a decrease in viral progeny when Vero cells were exposed to $100 \mu \mathrm{g} / \mathrm{mL}$ of $L$. alba or $L$. origanoides essential oil for $24 \mathrm{~h}$ and then were infected with YFV (Meneses et al. 2009). These results suggest that changes in the plasmatic membrane cell or intracellular environment that could interfere with the adsorption or intracellular steps of the viral cycle were not induced by treatment of the cell with the essential oil.

The precise mechanism of the virucidal action of essential oils is still not fully understood. Results of the studies evaluating the interference of the essential oil on steps of the viral infection cycle indicate that the inhibitory effect occurs during adsorption and penetration steps but not after penetration of the virus into the cell (Schuhmacher et al. 2003, Saddi et al. 2007, Koch et al. 2008). One could speculate that components present in the oil interfere with the virion envelope structures masking the $\mathrm{E}$ and $\mathrm{M}$ viral proteins, which are necessary for adsorption and entry into the host cell. The main components of the essential oils tested in this study were monoterpenes, including carvone, geranial, neral and limonene. Several kinds of terpenes have been shown to inactivate human immunodeficiency virus by inhibiting virus adsorption to the target cell and causing inactivation of the virus reverse transcriptase (Pengsuparp et al. 1994, Sun et al. 1996, Xu et al. 1996). Studies on the inhibitory effect of citral and limonene on YFV and DENV replication in vitro are in progress in our laboratory.

The essential oils tested exhibited high virucidal action on DENVs according to the adopted criteria. Nonetheless, there were differences in the $\mathrm{IC}_{50}$ values for $L$. alba oil with respect to other serotypes, albeit for $L$. citriodora it was observed for DENV-4 only. It is less plausible to be due to technical variations because the experiments simultaneously included all serotypes. It remains to be determined whether structural changes on the virion envelope due to essential oil components vary with respect to the virus serotype. Other studies have found variations in the antiviral activity with respect to dengue serotype when testing sulphated polysaccharide from the marine alga Cladosiphon okamuranus (Hidari et al. 2008), Gymnogongrus griffithsiae and Cryptonemia crenulata (Talarico et al. 2005).

The results of the present paper showed that the essential oil obtained from $L$. alba and L. citriodora had virucidal action on all four DENV serotypes and experiments were conducted for evaluation of direct in- activation on DENV-2 by incubation with the essential oils from other Colombian plants. L. origanoides, $P i-$ menta racemosa, Illiciom verum and Zingiber officinalis showed a $50 \%$ reduction of the viral plaque numbers at $100 \mu \mathrm{g} / \mathrm{mL}$ (unpublished data). In contrast, in studies evaluating the viral inhibitory effect of the essential oil from eight species of aromatic plants from Argentina, only Artemisia douglasiana and Eucalyptus patens had any discernible virucidal effect on DENV-2 replication in vitro (Garcia et al. 2003, Duschatzky et al. 2005).

Our results agree with other studies testing distinct natural products against DENV. Carbohydrate-binding agents originated from plant lectins can affect the binding of the virus to cell and subsequently inhibit viral replication (Talarico et al. 2007, Alen et al. 2009). Inhibitory activities by both extract and alkaloidal fraction of Uncaria tomentosa on infection rates and cytokine levels in treated monocytes-DENV infected have been reported (Reis et al. 2008). It seems that the zosteric acid derived from Zostera marina interferes with binding to the receptor required for DENV entry into the host cell (Rees et al. 2008). Anti-dengue activity of Hippophae rhamnoides leaf extract was demonstrated in DENV-2 infected blood-derived human macrophages (Jain et al 2008). In vitro and in vivo antiviral properties of sulphated galactomannans obtained from the marine alga against DENV have been reported (Ono et al. 2003, Hidari et al. 2008). Moreover, enveloped viruses distinct to flavivirus were also inactivated by treatment with the essential oil obtained from medicinal plants. The in vitro replication abilities of the herpes simplex virus, hepatitis $B$ virus and human immunodeficiency virus were suppressed by the previous exposure to essential oils but not by treatment of the cell with the essential oil before the adsorption of the virus (Zhang et al. 1988, Siddiqui et al. 1996, Yamasaki et al. 1998, Schuhmacher et al. 2003, Saddi et al. 2007, Koch et al. 2008).

The present paper has demonstrated the inhibitory effect of the essential oil obtained from $L$. alba and $L$. citriodora cultivated in Colombia on all four DENV serotypes. The essential oil seems to penetrate the skin and might act inside the cell to block viral replication (Carson et al. 2001). The topical use of the essential oil might be explored for prevention of virus infection through the bite of the vector mosquitoes.

\section{ACKNOWLEDGMENTS}

To Sergio Yebrail Gómez (CINTROP - Universidad Industrial de Santander, Bucaramanga, Colombia), for contributions to statistical analysis.

\section{REFERENCES}

Alen MM, Kaptein SJ, De Burghgraeve T, Balzarini J, Neyts J, Schols D 2009. Antiviral activity of carbohydrate-binding agents and the role of DC-SIGN in dengue virus infection. Virology 387: 67-75.

Carson C, Ashton L, Dry L, Smith D, Riley T 2001. Melaleuca alternifolia (tea tree) oil gel $(6 \%)$ for the treatment of recurrent herpes labialis. J Amtimicrob Chemother 48: 450-451.

Cos P, Vlietinck A, Berghe D, Maes L 2006. Anti-infective potential of natural products: how to develop a stronger in vitro 'proof-ofconcept'. J Ethnopharmacol 106: 290-302. 
Duschatzky C, Possetto M, Talarico L, Garcia C, Michis F, Almeida N, de Lampasona M, Schuff C, Damonte E 2005. Evaluation of chemical and antiviral properties of essential oils from South American plants. Antiviral Chem Chemother 16: 247-251.

Garcia C, Talarico L, Almeida N, Colombres S, Duschatzky C, Damonte E 2003. Virucidal activity of essential oils from aromatic plants of San Luis, Argentina. Phytotherapy Res 17: 1073-1075.

Gubler DJ 2006. Dengue/dengue haemorrhagic fever: history and current status. Novartis Foundation Symposium 277. In G Bock, $\mathrm{J}$ Goode, New treatment strategies for dengue and other flaviviral diseases, John Wiley, London, p. 3-16.

Halle W, Göres E 1987. Prediction of LD50 values by cell culture. Pharmazie 42: 245-248.

Hidari KI, Takahashi N, Arihara M, Nagaoka M, Morita K, Suzuki T 2008. Structure and anti-dengue virus activity of sulfated polysaccharide from a marine alga. Biochem Biophys Res Commun 376: 91-95.

Jain M, Ganju L, Katiyal A, Padwad Y, Mishra KP, Chanda S, Karan D, Yogendra KM, Sawhney RC 2008. Effect of Hippophae rhamnoides leaf extract against Dengue virus infection in human blood-derived macrophages. Phytomedicine 15: 793-799.

Jassim S, Naji M 2003. Novel antiviral agents: a medicinal plant perspective. J Appl Microb 95: 317-412.

Koch C, Reichling J, Schneele J, Schnitzler P 2008. Inhibitory effect of essential oils against herpes simplex virus type 2. Phytomedicine 15: 71-78.

Leyssen P, De Clercq E, Neyts J 2000. Perspective for the treatment of infections with Flaviviridae. Clin Microb Rev 13: 67-82.

Lindenbach B, Rice C 2007. Flaviviridae: the viruses and their replication. In D Knipe D, P Howley, Fields virology, Willians \& Wilkins, Philadelphia, p. 991-1041.

Meneses R, Ocazionez R, Martínez J, Stashenko E 2009. Inhibitory effect of essential oils obtained from plants grown in Colombia on yellow fever virus replication in vitro. Ann Clin Microbiol Antimicrob [serial on the Internet]. [cited 2009 March 6]; 8: [about 6 p.]. Available from: http://www.ann-clinmicrob.com/articles/ browse. asp?date $=3-2009$.

Ono L, Wollinger W, Rocco IM, Coimbra TL, Gorin PA, Sierakowski MR 2003. In vitro and in vivo antiviral properties of sulfated galactomannans against yellow fever virus (BeH111 strain) and dengue 1 virus (Hawaii strain). Antiviral Res 60: 201-208.

Pascual M, Slowing K, Carretero E, Sánchez-Mata D, Villar A 2001. Lippia: traditional uses, chemistry and pharmacology: a review. J Ethnopharmacol 76: 201-214.

Patkar Ch, Kuhn R 2006. Development of novel antivirals against flaviviruses. Novartis Foundation Symposium 277. In G Bock, J Goode, New treatment strategies for dengue and other flaviviral diseases, John Wiley, London, p. 41-52.

Pengsuparp T, Cai H, Fong S, Kinghorn A, Pezzuto J, Wani M, Wall M 1994. Pentacyclic triterpenes derived from Maprouneaafricana are potent inhibitors of HIV-1 reverse transcriptase. J Nat Prod 57: 415-418.

Rees CR, Costin JM, Fink RC, McMichael M, Fontaine KA, Isern S, Michael SF 2008. In vitro inhibition of dengue virus entry by p-sulfoxy-cinnamic acid and structurally related combinatorial chemistries. Antiviral Res 80: 135-142.
Reis SR, Valente LM, Sampaio AL, Siani AC, Gandini M, Azeredo EL, D’Avila LA, Mazzei JL, Henriques MG, Kubelka CF 2008. Immunomodulating and antiviral activities of Uncaria tomentosa on human monocytes infected with Dengue virus-2. Int Immunopharmacol 8: 468-476.

Saddi M, Sanna A, Cottiglia F, Chisu L, Casu L, Bonsignore L, De Logu A 2007. Antiherpevirus activity of Artemisia arborescens essential oil and inhibition of lateral diffusion in vero cells. Ann Clin Microb Antimicrob 6: 1-10.

Schuhmacher A, Reichling J, Schnitzler P 2003. Virucidal effect of peppermint oil on the enveloped viruses herpes simplex virus type 1 and type 2 in vitro. Phytomedicine 10: 504-510.

Siddiqui Y, Ettayebi M, Haddad A, Al-Ahdal M 1996. Effect of essential oils on the enveloped viruses: antiviral activity of oregano and glove oils on herpes simplex virus type 1 and Newcastle disease virus. Med Sci Res 24: 185-186.

Stashenko E, Jaramillo E, Martínez R 2004. Comparison of different extraction methods for the analysis of volatile secondary metabolites of Lippia alba (Mill.) N. E. Brown, grown in Colombia and evaluation of its in vitro antioxidant activity. J Chromatogrh 1025: 93-103.

Stashenko E, Ruiz C, Muñoz A, Castañeda M, Martínez J 2008. Composition and antioxidant activity of essential oils of Lippia origanoides HBK grown in Colombia. Nat Product Commun 3: 563-566.

Sun H, Qiu S, Lin L, Wang Z, Lin Z, Pengsuparp T, Pezzuto J, Fong H, Cordell G 1996. Farnsworth N: nigranoic acid, a triterpenoid from Schisandra sphaerandra that inhibits HIV-1 reverse transcriptase. J Nat Prod 59: 525-527.

Talarico LB, Duarte ME, Zibetti RG, Noseda MD, Damonte EB 2007. An algal-derived DL-galactan hybrid is an efficient preventing agent for in vitro dengue virus infection. Planta Med 73: $1464-1468$.

Talarico LB, Pujol CA, Zibetti RG, Faria PC, Noseda MD, Duarte ME, Damonte EB 2005. The antiviral activity of sulfated polysaccharides against dengue virus is dependent on virus serotype and host cell. Antiviral Res 66: 103-110.

Terblanche FC, Kornelius G 1996. Essential oil constituents of the genus Lippia (Verbenaceae) - A literature review. J Essent Oil Res 8: 471-485.

Wang QY, Patel SJ, Vangrevelinghe E, Xu HY, Rao R, Jaber D, Schul W, Gu F, Heudi O, Ma NL, Poh MK, Phong WY, Keller TH, Jacoby E, Vasudevan SG 2009. A small-molecule dengue virus entry inhibitor. Antimicrob Agents Chemother 53: 1823-1831.

Xu H, Zeng F, Wan M, Sim K 1996. Anti-HIV triterpene acids from Geum japonicum. J Nat Prod 59: 643-645.

Yamasaki K, Nakano M, Kawahata T, Mori H, Otake T, Ueba N, Oishi I, Inami R, Yamane M, Nadamura M, Murata H, Nakanishi T 1998. Anti-HIV-1 activity of herbs in labiates. Biol Pharm Bulletin 21: 829-833.

Zhang B, Chen J, Li H, Xu X 1998. Study on the Rheum palmatum volatile oil against $\mathrm{HBV}$ in cell culture in vitro. Zhong Yao Cai 21: 524-526.

Zhou Z, Khaliq M, Suk JE, Patkar C, Li L, Kuhn RJ, Post, CB 2008. Antiviral compounds discovered by virtual screening of smallmolecule libraries against dengue virus E protein. ACS Chem Biol 3: 765-775. 